Cely, N. (2016). La primera edad del cine en Bogotá. Revista de Sociología y Antropología: VIRAJES, 18 (1), 181-215. DOI: 10.17151/rasv.2016.18.1.9

\title{
LA PRIMERA EDAD DEL CINE EN BOGOTÁ*
}

\section{NICOLÁS CELY MUÑOZ**}

Recibido: 27 de agosto de 2015 Aprobado: 15 de noviembre de 2015

Artículo de Investigación

\footnotetext{
* Artículo de reflexión desarrollado en el marco de una investigación realizada para la clase de Análisis Social Cualitativo, del Departamento de Sociología de la Universidad Javeriana dictada por el Profesor Nelson Gómez Serrudo.

** Politólogo y Sociólogo de la Universidad Javeriana de Bogotá. Cursa actualmente la Maestría de Estudios Políticos en el IEPRI en la Universidad Nacional de Colombia., Bogotá, Colombia. Pontificia Universidad Javeriana. ncely@javeriana.edu.co 으 ORCID: 0000-0003-4528-7490
} 


\title{
Resumen
}

El artículo explora la manera en que el cine se estableció en Bogotá en las primeras décadas del siglo XX como un espectáculo cultural y evento social donde confluyeron la participación de tres actores principales: los empresarios que hicieron del cine un negocio, las instituciones oficiales que vieron en el cine una actividad a ser regulada y el público que activamente planteó una relación dinámica durante las funciones. Se introducirá el concepto de experiencia de cine para recoger los elementos que dotaban de sentido "ver cine", y templos del entretenimiento para señalar cómo los lugares donde se comenzó a proyectar cine de manera permanente, se esforzaron por hacer de la experiencia un completo festín del ocio.

Palabras clave: Templos del entretenimiento, experiencia del cine, noche, publicidad, Bogotá, público.

\section{THE FIRST AGE OF CINEMA IN BOGOTÁ}

\begin{abstract}
The article explores the way cinema established itself in Bogota in the early decades of the twentieth century, as a cultural show and relevant social event where the participation of three main actors converged: entrepreneurs that made the cinema a business, official institutions who saw in the cinema an activity to be regulated and the public who actively established a dynamic relationship during the performances. The concept of cinema experience will be introduced to collect the items that gave meaning to "watch movies", and entertainment temples to point out how the places where film started an ongoing project strove to make the experience a complete feast of leisure.
\end{abstract}

Key words: Temples of entertainment, film experience, night, advertising, Bogotá, public. 


\section{La llegada del cine a la ciudad ${ }^{1}$}

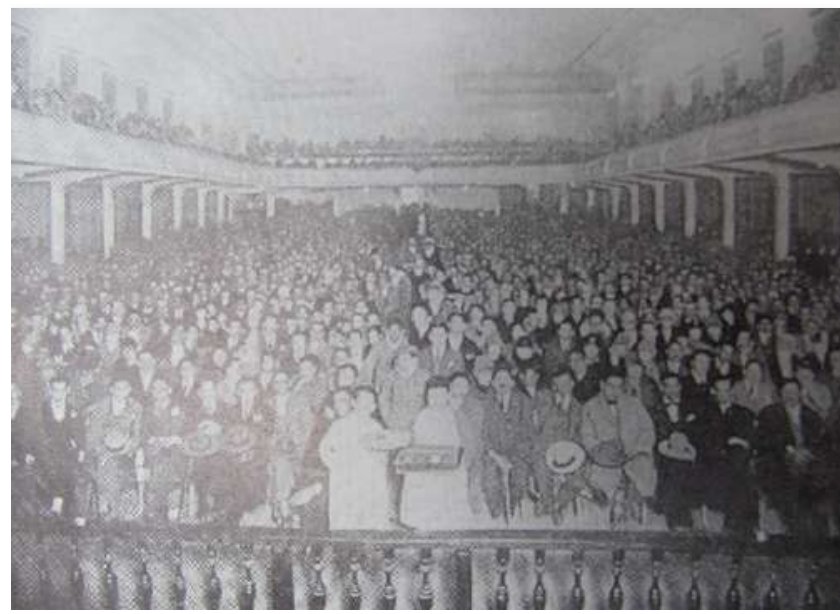

Fotografía 1: Interior Teatro Faenza (1929). Fuente Índex Colombia.

En Bogotá Siglo XX: Urbanismo, arquitectura y vida urbana (Saldarriaga Roa, 2000).

Qué desagradable sensación cuando se encendían las luces: había naufragado en el amor de los personajes y estos desaparecían, llevándose su mundo con ellos. Había sentido su victoria en mis huesos, y sin embargo era suya, no mía. En la calle me parecía estar de más. Jean Paul Sartre. (Geduld, 1981, p. 60).

Es indudable que el cine despierta pasiones y emociones, una vez se apagan las luces del teatro, la ficción se convierte en nuestra realidad por unos breves momentos. Este sentimiento es universal, y sin embargo en cada latitud donde se ha proyectado cine, guarda detrás una historia

\footnotetext{
${ }^{1}$ Previo a entrar en materia es pertinente hacer unas precisiones de cómo se procedió metodológicamente. De manera general se construyó una base de datos nutrida de registros tanto de fuentes primarias como de fuentes secundarias. Sobre las fuentes primarias, la recolección de datos se hizo fundamentalmente por medio de un trabajo en archivo (directamente en la Biblioteca Nacional), en el que se revisaron sistemáticamente los registros de las revistas especializadas en cine que para los años del periodo de estudio eran referente en Bogotá, siendo la revista Olympia en un primer momento y más tarde la revista Películas. El cine, al convertirse en un suceso social importante en los primeros años del siglo XX en Bogotá, era indudable que sus repercusiones en diferentes ámbitos iban a tener algún impacto en la prensa escrita, es por tal motivo que también se realizó una revisión de prensa para el periodo señalado en el periódico El Tiempo, principal diario bogotano del momento. La búsqueda de registros no fue al azar, se hizo en función de las categorías de análisis que orientan la reflexión, siendo las relaciones cineempresa, cine-institucionalidad, público-cine, la configuración de un medio cinematográfico en Bogotá, el cine como espectáculo y el desarrollo de los espacios y la infraestructura para exhibir el cine.

Las fuentes secundarias a las que se recurrieron fueron principalmente investigaciones sobre el devenir histórico del cine en Colombia, particularmente en Bogotá, adelantadas por la Fundación Patrimonio Fílmico de Colombia y otras publicaciones enfocadas hacia la arquitectura y toda la infraestructura acondicionada en aquellos años en la capital para la exhibición de cine.
} 
particular de la manera en que esa sociedad lo experimentó.

La primera función de cine en Bogotá tuvo lugar un miércoles primero de septiembre en el antiguo Teatro Municipal. Ernesto Vieco ofreció una función con su máquina cinematógrafo, la cual los cronistas no dudaron en calificar de hechicera criatura (Nieto y Rojas, 1992). Se vislumbraba de a poco el impacto que el cine habría de tener en las nuevas formas de divertimento y entretenimiento en la ciudad a lo largo del siglo XX.

Los orígenes del cine en Bogotá estarían inexorablemente unidos al apellido Di Doménico. Francisco y Vicenzo eran dos hermanos provenientes de Italia que habían venido presentando funciones con su aparato cinematógrafo de manera itinerante en el Caribe y dieron funciones exitosas en el Teatro Municipal de Barranquilla, posteriormente se adentrarían al centro del país.

\section{El floreciente negocio de la cinematografía en Bogotá}

Va ya para un lustro que, acogidos fraternalmente por esta culta sociedad, hubimos de plantar aquí nuestra tienda de peregrinos del arte. (Di Doménico Hnos). ${ }^{2}$

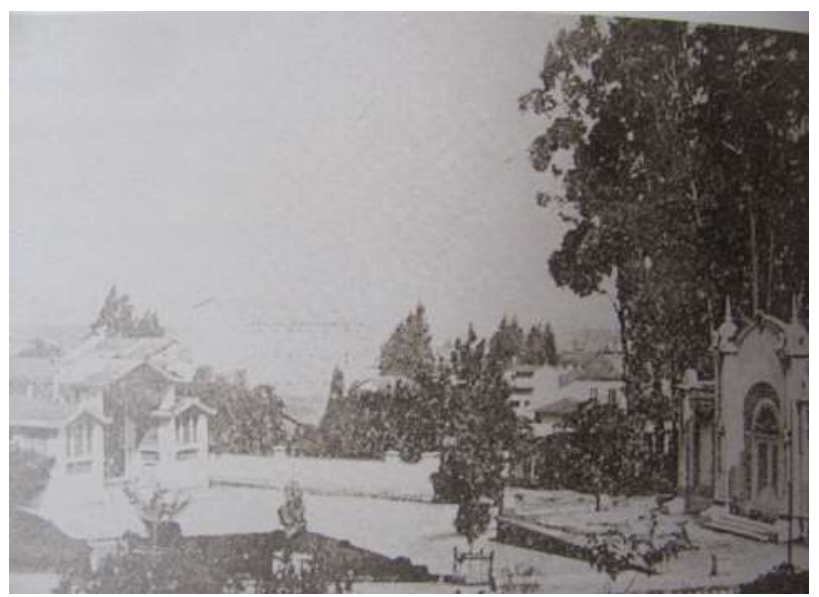

Fotografía 2: Parque de la independencia: Pabellón de la mecánica a la izquierda y Pabellón Egipcio a la derecha (Cromos, diciembre de 1920).

Con motivo del centenario del grito de independencia, entre las festividades se inauguró el Parque de la Independencia, donde tuvieron

\footnotetext{
${ }^{2}$ Nota Lo del Sábado, en Revista Olympia, 21 de agosto de 1915.
} 
lugar diferentes exposiciones. Ocupó los terrenos del llamado Bosque San Diego, localizado en el extremo norte de la ciudad, entre lo que hoy son las calles 24 y 26 y las carreras quinta y séptima. Para la exposición se construyeron 6 pabellones especiales dedicados a mostrar diferentes aspectos de la vida del país (Saldarriaga, 2000). El Pabellón de la Mecánica sería utilizado después de la exposición del centenario como escenario de cine, administrado por la Beneficencia (Nieto y Rojas, 1992). También conocido como el Salón del Bosque o el Salón del Parque o el Pabellón de la Industria, aquí sería donde dos forasteros italianos comenzaron a ganarse un nombre entre los bogotanos y dominar la escena del cine en la ciudad: Los hermanos Di Doménico.

En palabras de Francisco Di Doménico:

Contraté con el gobierno para trabajar en el Parque de la Independencia o San Diego donde había un salón para obras públicas. Me pagaban 30 dólares cada noche, además de una función para mi propio beneficio. Me contrataron para 30 funciones pero hice otras 50, además de 300 pesos ganados con las proyecciones en mi propio beneficio. Reuní así una buena suma. (Nieto y Rojas, 1992)

Estas palabras dan una idea de lo provechoso que podía ser el negocio de proyectar filmes pero sobre todo el potencial de lucro que tenía este aún muy poco explotado negocio en Bogotá, no por nada después de transitar errantemente, los Di Doménico finalmente verían en Bogotá el lugar propicio para establecerse y conformar una sociedad cinematográfica dedicada a la compra y venta de filmes, pero sobre todo para proyectar funciones a un público bogotano ávido de películas.

Los Di Doménico no eran los únicos conscientes de la exaltación que suscitaba el cine en los bogotanos, un grupo de empresarios colombianos también se la jugaron por explotar dicho negocio. Francisco Pardo, como lo relataría Francesco Di Doménico, les quitaría el contrato del Parque de la Independencia para proyectar sus filmes, forzándolos a mudarse al Teatro Municipal. Vicenzo Di Doménico regresaría del exterior con nuevas películas y con Fonzino Sessa, quien trabajaría con ellos. Por su parte, Pardo no lograba hacer ninguna proyección como las que hicieron los Di Doménico anteriormente, el público comenzó a silbarlo y entonces tuvo que recurrir a la ayuda de los Di Doménico (Nieto y Rojas, 1992).

Para la época Bogotá no tendría un lugar especialmente construido para presentar cine, tendría en cambio lugares adaptados para tal fin. Para una muestra, la segunda planta del Bazar Veracruz (edificio construido 
por Leo Kopp para el comercio) situado en la Calle Real (lo que hoy es la carrera séptima entre calles doce y trece) había sido convertida en sala de representaciones y comenzó a presentar funciones en cinematógrafo en 1909 (Nieto y Rojas, 1992). El Bazar Veracruz también será un lugar donde los Di Doménico presentarían sus filmes hacia 1911.

Tanto el Salón del Bosque como el Teatro Municipal y el Teatro Variedades (Bazar Veracruz) donde se realizaron algunas de las primeras proyecciones, eran salas destinadas a presentar diversos espectáculos y ocasionalmente se adaptaron para proyectar cine antes de 1912 (FPFC, p. 12). Toma fuerza la idea de construir un primer gran salón diseñado teniendo en cuenta las funciones de cine, y dejar así en el pasado un cine primordialmente ambulante.

Los Di Doménico, confiados de la rentabilidad del negocio, se embarcan en la búsqueda de empresarios que financien su pequeña aventura de construir la primera sala fija de cine en Bogotá, evidencia de un aún muy escueto desarrollo de la industria cinematográfica en el país, pues mientras en Bogotá la gente veía todavía cine en sabanas extendidas en plazas y parques, Estados Unidos (una potencia consolidada para el momento en producción cinematográfica) contaba con alrededor de 7000 salas de cine en todo el país, mientras que solamente en París existían alrededor de 300 (Nieto y Rojas,1992). Entre los empresarios que aceptan la propuesta y aportan su capital para la construcción de la sala, se encuentran los señores bogotanos Ulpiano Valenzuela y Nemesio Camacho (FPFC, p. 12).

Se inaugura así el 8 de diciembre de 1912 el Salón Olympia, cuyo nombre hacía remembranza al Cinema Olympia, el más importante salón para espectáculos de la época en Italia (Ávila y López, 2006, p. 24). Se inauguró con la película El último de los Frongtiac comúnmente conocida como Novela de un joven pobre, por ser el nombre de la novela literaria que inspiró la película (Nieto y Rojas, 1992).

Con el aumento de su popularidad a cuyo nombre se ligaba el Salón Olympia, los Di Doménico ${ }^{3}$ dan el siguiente paso hacia la consolidación de su supremacía en la industria cinematográfica del país. El 14 de julio de 1914 dan vida a la Sociedad Industrial Cinematográfica Latinoamericana (SICLA), una sociedad perteneciente a la Empresa Di Doménico Hnos. Sus anuncios publicitarios en El Tiempo solían ocupar gran parte de la portada: (La SICLA) “Vende y alquila películas francesas de corto y largo metraje. Precios desde 10 centavos". Pronto ampliarían su portafolio de servicios, así lo anuncia la revista Películas que se editaba en 1916: “Fábrica de películas

\footnotetext{
${ }^{3}$ Francesco era conocido por los bogotanos como "el italiano de la máquina" . En Nieto y Rojas, p. 48, 1992.
} 
nacionales. Únicos concesionarios de la Casa Ítala Film”"4; o como se observa en otro aviso publicitario:

Di Doménico Hnos., industria especializada en el negocio de la cinematografía. Tenemos las mejores películas europeas y americanas, así mismo tenemos máquinas de proyección, carbones, fotografías, carteles, cemento y toda clase de accesorios usados en el negocio cinematográfico ${ }^{5}$.

Sumado a esto, en vista del doble uso que se podía dar al cinematógrafo, tanto para proyectar como para filmar, se multiplicaron las posibilidades de disponer de material de proyección y diversificar así las fuentes de ingreso de los propietarios que se convirtieron también en realizadores de documentales (Ávila y López, 2006). En el Olympia se exhibía, sobre todo, material cinematográfico italiano y francés. De la misma manera se registraban en película cinematográfica los paseos matutinos de los principales habitantes de Bogotá, estos registros se aprovechaban como gancho comercial para atraer al público (FPFC, p. 12). ¿Y cómo no? Una cosa es ver paisajes, personas e historias que suceden en partes lejanas del mundo que tal vez nunca lleguen a conocer, y otra muy distinta, ver a la propia ciudad, los lugares y gente conocida, verse a sí mismos, esto causa emoción y sobretodo curiosidad, así pues los cortos de los Di Domenico eran imanes de gente que asistía con la expectativa de quizás aparecer "por accidente" en alguno de ellos. La primera película de acontecimientos locales en Bogotá realizada por Di Doménico se estrenó el 17 de junio de 1915 y se promocionó como "La primera película nacional: La fiesta del Corpus y de San Antonio" (Nieto y Rojas, 1992).

En 1919, la SICLA firmaría un contrato con la Casa Pathé de Paris para la compra y explotación en sus salones de las revistas Pathé (Pathé Journal), que no debemos confundir con publicaciones o magazines, sino que de hecho eran rollos de cintas con temas de actualidad mundial que se proyectaban ${ }^{6}$ y que gozarían de un éxito formidable entre el público bogotano. Por otra parte, la marca Pathé de París habría de ampliar su incursión en el mercado de cine en Bogotá a través del Almacén Pathé-Baby, en la esquina del entonces Banco de Bogotá, donde como su nombre lo indica, vendían películas Pathé Baby (nombre del proyector que las rodaba). Eran películas en 9,5 mm que llegaban como remesas de Francia y se volvieron muy populares porque el proyector era de tamaño reducido y

\footnotetext{
${ }^{4}$ Aviso publicitario SICLA en revista Películas, p. 4, 2 de diciembre de 1916.

${ }^{5}$ Aviso publicitario empresa Di Doménico Hnos. En revista Películas. p. 4, 26 de septiembre de 1916.

${ }^{6}$ Ver nota Revista Pathé (Pathé Journal) en revista Películas, número 121, abril de 1919.
} 
compacto, lo cual permitía reproducir películas en espacios como la casa y lugares más privados.

Por su parte, Arturo Acevedo Vallarino y sus hijos Gonzalo y Álvaro Acevedo Bernal, fundan en 1920 la Casa Cinematográfica Colombia. Realizan los noticieros Bogotá en pie y Noticiero Nacional (IDARTES, 2012). También estaba El Kine, cuyos orígenes se remontan a funciones ambulantes por distintos salones y locales de la costa atlántica, bajo los nombres de "Kinematógrafos", "Kine Universal" y "Universal" . En Bogotá, la empresa había tenido temporadas en el Municipal, en el Variedades y en el Palacio del Tango hasta llegar al Salón del Bosque (Nieto y Rojas, 1992).

No en pocas ocasiones la proyección de cine fue motivo de congregación para causas nobles, que desde luego sin caer en la ingenuidad, eran ganchos comerciales favorables pues si se destinaban noches o galas a beneficio de cierta causa en particular, el mensaje que se enviaba era que el salón o teatro en cuestión lo movían intereses no únicamente utilitaristas, sin mencionar la buena publicidad que le hacían a sus películas. Las noches o galas dedicadas a beneficio de una causa fueron auténticas ceremonias planificadas por los dueños, a las que la gente respondió con una asistencia masiva. Servía así el cine como elemento articulador de la movilización social hacia distintas causas sociales y obras de caridad. El cine era la excusa perfecta.

Por mencionar algunas de estas causas sociales: "a beneficio del Barrio Obrero" ,"para los damnificados del incendio en Girardot", "para las víctimas de los temblores en el Oriente", "a beneficio de actrices y compañías de teatro", "para los huérfanos de la guerra", "para vestir a los niños pobres en el centenario de la Batalla de Boyacá", "para la Cruz Roja", "para el dormitorio de la infancia desamparada", "para el asilo de locas", "para el sindicato de la aguja", "para los empleados del Salón", entre muchas otras (Nieto y Rojas, 1992). Era muy común que los salones y teatros destinaran veladas a beneficio de los empleados de sus establecimientos, algo interesante de esto es que los dueños de los otros salones y establecimientos, percatados de esta situación optaban por cerrar sus puertas esa noche y colaborar así con la causa de la competencia, cosa que debemos advertir no sólo como la solidaridad recíproca entre estos primeros empresarios, sino también la capacidad del cine para generar una ganancia considerable en la medida en que los dueños de estos establecimientos podían darse el lujo de cerrar por una noche sin verse gravemente afectados.

La gran concurrencia a estas veladas de beneficencia quedaría plasmada en una noticia de la revista Olympia de octubre de 1915 donde se informaba de la afluencia del público a la función del pasado martes, que desde las siete de la noche el salón estaba ocupado por damas y caballeros, 
y a las ocho, la multitud era tal, que difícilmente podían caminar los que ya se habían quedado sin asiento. El público que no quería quedarse por fuera de tal acontecimiento, estuvo dispuesto a pagar las localidades al precio que pedían los revendedores ${ }^{7}$.

En el apogeo de su trayectoria, las empresas SICLA y Di Doménico Hnos. y Co. importaban y distribuían películas americanas y europeas, producían noticieros nacionales y largometrajes de argumento, organizaban funciones y giras y otros espectáculos, manejaban su publicidad mediante imprentas que controlaban, representaban casas fabricantes de equipos cinematográficos y teatrales (Nieto y Rojas, 1992). El Salón Olympia y las dependencias y solares que los complementaban por detrás, serían lugares que se convertirían en escenarios para películas filmadas por la SICLA.

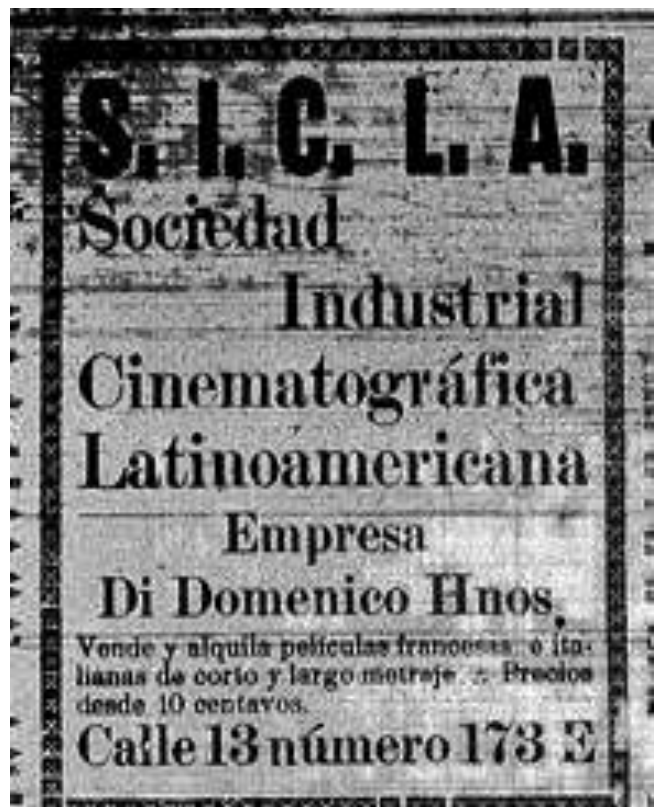

Fotografía 3: Anuncio publicitario S.I.C.L.A.

En El Tiempo, 4 de mayo de 1914.

Ese primer gran auge de la empresa cinematográfica en Bogotá finalizaría hacia 1928, cuando la empresa SICLA, sus equipos, estudios y laboratorios, fueron vendidos a la naciente Cine Colombia, que se dedicaría exclusivamente a la distribución de cine norteamericano y extranjero. Durante los años siguientes la producción se redujo a la realización de noticieros semanales sobre la vida nacional (IDARTES, 2012).

\footnotetext{
${ }^{7}$ Ver nota La función del martes, en Olympia, p. 1, 2 de octubre de 1915.
} 


\section{Templos del entretenimiento}

“Mi salón de cine es el del Olympia. Lo prefiero por lo grande, fresco y cómodo. Y sobre todo por la Orquesta"

Un templo es definido comúnmente como el lugar en el que se rinde culto a una religión, a un arte o a una ciencia. Los teatros y salas de cine que fueron construidos en las primeras décadas del siglo XX en Bogotá le rendían culto no únicamente al cine, sino al entretenimiento en todas sus formas. Cada pequeño detalle, desde su construcción como edificios grandes y espaciosos, así como su decoración interior, su estética elegante, sus salones para intermedios, y sobre todo las distintas actividades que allí podían tener lugar, habían sido especialmente pensadas para ofrecer al asistente una experiencia cautivadora y definitiva de placer. $\mathrm{Si}$ a las iglesias los bogotanos asistían a rezarle a Dios, a los teatros y salas de cine concurrían a expresar su devoción por el entretenimiento.

La exhibición de películas en Bogotá se realizaba en plazas y parques públicos o en salones y en teatros reconocidos como centros de diversión, copiando en parte la moda norte-americana de los music-halls o los penny-arcades, locales de atracciones con juegos y eléctricos y mecánicos de las grandes ciudades (Ávila y López, 2006). Sin embargo, este tipo de presentación del cine correspondía a la ausencia de una iniciativa planeada y estructurada por comercializar de manera eficiente y masiva el producto del cine y verdaderamente levantar un negocio rentable alrededor del mismo, como ya venía ocurriendo en las grandes urbes del entretenimiento en Europa y Estados Unidos.

El cine se instaló en Bogotá (como en todas las ciudades a las que llegó) de manera improvisada en espacios abiertos o en edificios destinados a otros usos en los cuales se acondicionaban los equipos y el mobiliario mínimo para ofrecer el servicio de exhibición de cine. Los primeros empresarios del cine en Bogotá fueron pioneros que recurrieron a adaptaciones improvisadas de sitios como vestíbulos y salas de teatros, espacios religiosos, patios o salones grandes de casas, terrazas de edificios, jardines, parques y plazas públicas y espacios baldíos en los cuales levantaban sencillas estructuras de madera y lamina o carpas de lona del estilo de las ferias y los circos (Ávila y López, 2006). Para 1910 funcionaban principalmente cuatro salones donde se proyectaba cine (y ninguno de los cuales había sido construido para tal fin), a saber: el Teatro Municipal, el Bazar Veracruz, el Pabellón de Mecánica, San Victorino (Nieto y Rojas, 1992).

Tener un espacio principalmente dedicado a la proyección del cine

${ }^{8}$ Ver en nota La 'velada' de anoche, en revista Películas, número 123, junio de 1919. 
tenía sus especificidades técnicas. Como por ejemplo la necesidad de especificar el manejo y protección de los equipos de proyección y de las películas de celuloide, que debía ser solucionada aislando el equipo de proyección de la sala, por lo cual en las construcciones se generalizó el uso de la caseta cerrada que cumplía con los mínimos requerimientos de seguridad (Ávila y López, 2006).

El salón Olympia sin duda significó un hito para los espacios de cine en Bogotá, se convirtió en el primer gran espacio cubierto de carácter masivo y popular dedicado a la exhibición cinematográfica y también a otros espectáculos. El salón medía 70m de largo en sentido este-oeste y 30m de ancho en sentido norte-sur. Se usaban bancas largas de madera "durísimas para los glúteos" . Su fachada comenzaba media cuadra al occidente de la carrera séptima y se desarrollaba a lo largo de unos 70 a 80 metros, con 10 arcos que servían de entrada y salida y adornos en lo alto. Al frente del salón quedaba la estatua de La Rebeca (Nieto y Rojas, 1992). Adentro, su arquitectura era sencilla, aludía a detalles en yesería, muros, cielos rasos decorados con pinturas alegóricas (Montaño, 2010).

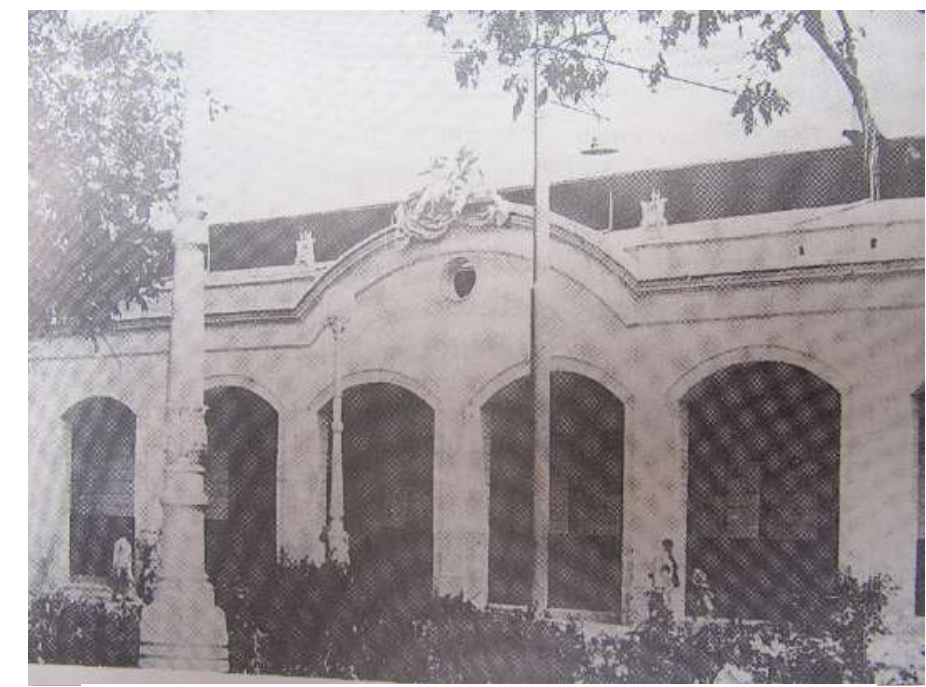

Fotografía 4: Exterior Salón Olympia. En Bogotá Siglo XX: Urbanismo, Arquitectura y Vida Urbana (Saldarriaga Roa, 2000).

Fue con la apertura del salón Olympia que se hizo habitual la presencia de orquestas para amenizar los programas durante la proyección de la película central y los intermedios. La mención de las agrupaciones musicales era un ingrediente fundamental en la promoción del espectáculo: Orquesta Conti, Orquesta del Maestro Velasco e incluso la Orquesta del 
Salón Olympia (Nieto y Rojas, 1992). El Olympia no era el único salón que acostumbraba a utilizar orquestas musicales para acompañar los filmes, su uso era común ya que al ser el cine mudo, la música en gran medida marcaba el tono de las escenas. Así lo muestra la sección de Espectáculos para hoy sábado de El Tiempo en 1914: Estreno Gran Salón Olympia: El triunfo de la fuerza, Obertura Orquesta Conti; Kine Universal en el Bosque: Las sorpresas del divorcio, Obertura Orquesta Unión Musical; Kine en Teatro Municipal: Juana la maldita, Obertura Orquesta Unión Musical 9.

El salón Olympia no sería el único en la carrera por el cine, en los años siguientes a su inauguración vendrían otros teatros especialmente pensados para proyectar cine siguiendo esa idea de espectáculo que vendía el Olympia. El teatro Thalía fue inaugurado en 1913, abierto en Chapinero para los veraneantes del "Versalles bogotano" con funciones de cine y sesiones de patines (Ávila y López, 2006). Vendrían luego respectivamente el teatro Cinerama en 1915 (adaptado para el cine), el teatro Caldas en 1917, el Apolo en 1918, el Moderno en 1918, el teatro Bogotá en 1918, el teatro Nariño en 1920, el cine Real en 1920, el edificio Círculo de obreros en 1922 (adaptado) y el Teatro Faenza en 1924 (Ávila y López, 2006).

El teatro Bogotá estaba ubicado en la parte alta de la calle 20 con más de 120 palcos y con capacidad para 2000 espectadores (Ávila y López, 2006). Estaba situado en la calle 20 a pocas cuadras del camellón de las Nieves, su constructor, el ingeniero Arturo Jaramillo recibió el encargo del R.P. Posada de la comunidad de San Francisco (FPFC, p. 19).

Entre las salas construidas prevaleció la tipología salón-teatro, más cercano al programa arquitectónico propio de los teatros tradicionales, en el cual la luneta era un amplio espacio con hileras de butacas que inicialmente no estaban fijadas al piso, rodeado de palcos circundantes (Ávila y López, 2006). Los nuevos teatros se construyeron siguiendo ciertos rasgos del diseño del teatro tradicional: cuentan con una buena capacidad de espectadores, mantienen la relación acceso-hall-foyer, manejan efectos lumínicos y una cuidadosa decoración, usan música en vivo y como complemento adaptan salones de té o café y restaurantes (Montaño, 2010).

Bogotá incorporaría progresivamente en su paisaje urbanístico una arquitectura que buscaba convocar a los espectadores del cine a través de operaciones formales y la apropiación de elementos arquitectónicos que hacían referencia a estilos propios de las vanguardias de principio de siglo que se manifestaban en Estados Unidos y en Europa, como el Art Nouveau y el Art Déco (Montaño, 2010).

\footnotetext{
${ }^{9}$ Espectáculos para hoy sábado. El Tiempo p. 3, 31 de enero de 1914.
} 
Una muestra es el Teatro Faenza, uno de los primeros edificios de la arquitectura colombiana en incorporar el concreto reforzado como novedosa técnica de construcción para la época, y por el diseño de la fachada caracterizada por su arco y detalles que remiten al estilo Art Nouveau, caracterizado por una mezcla de ricos motivos ornamentales y el uso de líneas curvas y ondulantes, no obstante también incluye referencias al estilo neoclásico y al Art Decó. Su diseñador, Juan Ernesto González Concha, combinó tendencias neoclásicas y modernas que se tradujeron en la riqueza espacial y ornamental del teatro (Montaño, 2010).

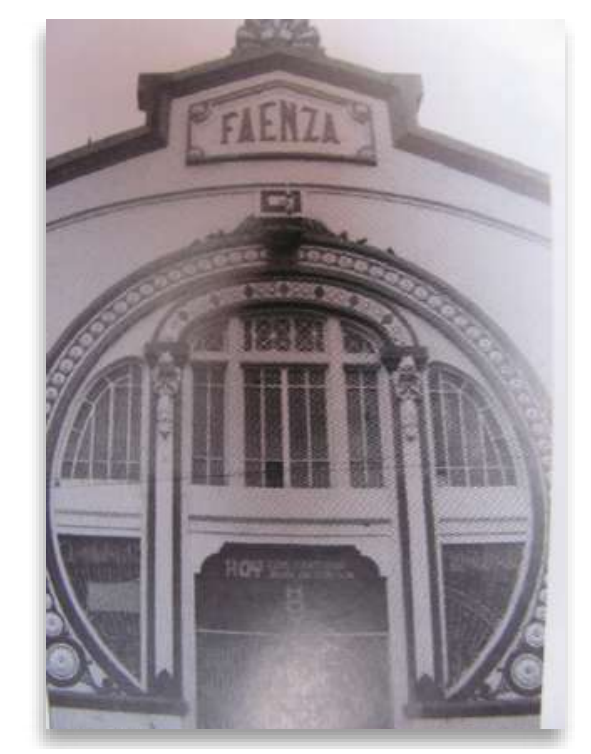

Fotografía 5: Exterior Teatro Faenza (1924).

En Salas de cine (Ávila y López, 2006).

Además, contaba con una platea amplia y un palco en forma de herradura, en el segundo nivel había un foyer que servía como salón de té. Contaba también con un escenario provisto de tramoya que permitía, además de la proyección de cine, representaciones escénicas y obras de ópera y zarzuela (Montaño, 2010). Así mismo, impuso un modelo de sala múltiple apta para funciones de cine y de teatro, combinado con un salón de té templado para que se reunieran las damas que asistían a la función de matiné. Ese modelo se replicó posteriormente en otras salas importantes entre las que sobresalen el teatro San Jorge y el teatro Colombia (Saldarriaga, 2000). 
Un auténtico templo del entretenimiento ofrece algo más que exclusivamente una película, sino todo un conjunto de actividades complementarias para hacer de la experiencia algo completo y variado, pero sobre todo para mantener a sus asistentes tan entretenidos como sea posible, de ahí que ningún momento dentro del teatro fuese dejado en el "vacío", se hacía un gran esfuerzo por que cada momento sostuviera un gozo implícito, el objetivo principal era mantener al público entretenido dentro de sus muros por el mayor tiempo posible. El intermedio era un momento importante en la proyección del cine de la época, muestra que el intermedio de una película no significa un cese del esparcimiento.

El intermedio era el espacio de tiempo en que la película era detenida, normalmente para hacer un cambio de carrete, y se invitaba a la gente a tomar bebidas y comidas en la cafetería, en los salones de té o en los corredores aledaños a la sala de proyección. Durante el intermedio se proyectaban los noticieros de la época o presentaban shows de magia. Se conformaban "programas" que no sólo tenían noticieros, sino cortos de animación o una película de "relleno" además de la principal; el conjunto era adquirido a veces por una sola boleta y constituía un verdadero "plan" por durar hasta más de cuatro horas (IDARTES, 2012).

Además de las proyecciones se realizaban conciertos, bailes, reinados, números de patinaje, bodas y todo tipo de fiestas, así como asambleas y combates de boxeo (Ávila y López, 2006). Una de las actividades más comunes, promovida sobre todo desde el Olympia, eran las sesiones de patinaje que tenían lugar en el propio salón. Para estas sesiones se retiraban las largas bancas de madera en que la gente se sentaba para ver las funciones y se convertía el salón en una gran pista de patinaje. Bastaba con comprar una boleta y los patines serían provistos, de igual forma se realizaban frecuentemente concursos con premios para patinadores.

Estas sesiones de patinaje constituían oportunidades de interacción social en salas de cine aun cuando no fueran proyecciones de filmes en lo absoluto, y estas interacciones en no pocas ocasiones trascendían a roces y controversias. Para un ejemplo la advertencia que hace en uno de sus números la revista Películas:

Para evitar desórdenes, confusiones y reclamos en las funciones de patines, y a fin de cumplir más estrictamente el reglamento, de esta fecha en adelante, toda señorita que desee patinar, debe ir provista de una boleta especial que debe ser solicitada en la oficina de Di Doménico, por el padre o hermano de ella. De la misma manera, a todo varón que no guarde la compostura debida y a quien sea preciso 
dar clases de buena educación, les serán negados los patines en las sesiones próximas ${ }^{10}$.

Durante las sesiones de patinaje eran frecuentes los altercados con las mujeres que se veían insultadas por el comportamiento soez de hombres que les dirigían comentarios bruscos y descorteses, de ahí la intención de la empresa por exhortar a las señoritas ir acompañadas por un hombre (su hermano o su padre) de tal forma que no estuvieran indefensas frente a estos hombres toscos a quienes se les pedía un comportamiento más respetuoso y mesurado.

A pesar de la avasalladora introducción de los teatros y salas especialmente construidas para proyectar cine, éste no se desplaza del todo a estos recintos y se sigue presentando en los teatros y locales que ya eran habituales como el Municipal, el Variedades y el del Bosque, además también frecuentan la ciudad de pasada el cine Parisiana, que funcionaba en el barrio Las Cruces, posiblemente en la plaza, el "Cinematógrafo Ambos Mundos del señor Bravo", el proyector del Circo Teatro Nacional La Favorita, el Cinema Eclair, "el cinematógrafo Minerva del señor Piedrahita", "el Cinematógrafo del señor Herran", y el "señor Zimmerman y su aparato" ( Nieto y Rojas, 1992).

Aun cuando los teatros y salones concebidos para presentar cine se construyeron con tal fin, subyacía en ellos una aspiración de convertirlos en "algo más" que meras salas de cine, de erigirlos como lugares especializados y con todas las facilidades del caso para que confluyera en su interior toda la experiencia de entretenimiento, de tal forma que serán recurrentes los constantes esfuerzos de los propietarios por brindar una última experiencia de satisfacción y de placer a sus asistentes desde los espectáculos y actividades que ofrecían. El ocio y el divertimento comenzaron a girar alrededor de estos lugares.

En 1945, las ínfulas de desarrollo urbano y modernizador en la ciudad arrasan con el Gran Salón Olympia, para darle paso a la ampliación de las carreras novena y décima. Aquel coloso del espectáculo sobre el cual se pueden contar miles de historias, era demolido y con él se iba también una esplendorosa época del cine en Bogotá, la de los templos del entretenimiento y se advendría una nueva forma de ver cine en los años siguientes.

\footnotetext{
${ }^{10}$ Ver en Películas, noticia Patines p. 3, 23 de septiembre de 1916.
} 


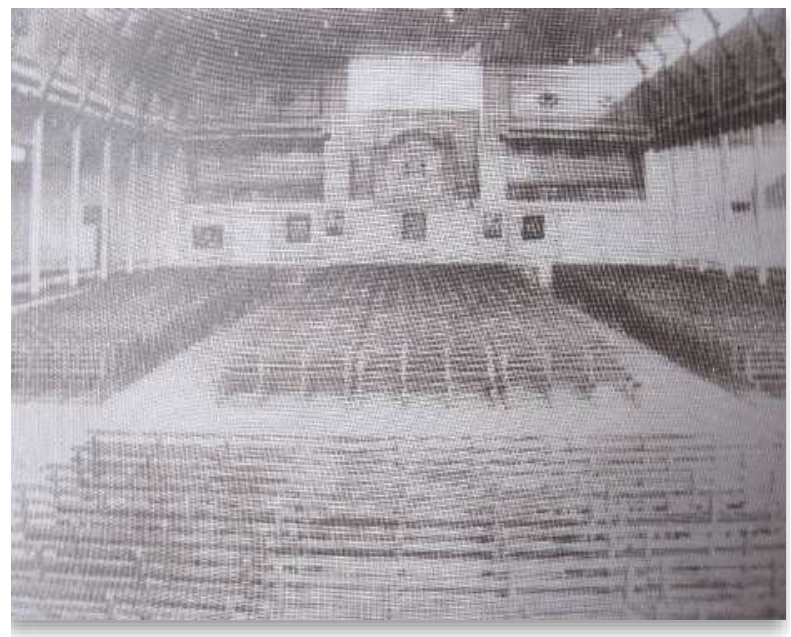

Fotografía 6: Interior Salón Olympia. En Los Tiempos del Olympia

(Nieto y Rojas, 1992).

\section{La difusión del cine en la sociedad bogotana}

¿Será posible que el público se canse del cinematógrafo? Yo no lo creo. Al contrario, observo que cada día se perfecciona y cobra más auge ese especial arte de las películas, que es a no dudarlo, el que se presta mejor a la variedad. (Atilano Pérez) ${ }^{11}$

El cine, en relación con otras expresiones artísticas como el teatro o las presentaciones musicales, tuvo un desarrollo más tardío por cuenta del avance del cinematógrafo a penas hacia finales del siglo XIX. Entró directamente a competir con otras expresiones artísticas y manifestaciones culturales, buscando ganarse un sitio dentro del favor del público. En su contra tenía la costumbre, pues otras formas de entretenimiento ya habían echado raíces, pero a su favor lo insólito y "hechicero" de la imagen en movimiento. Fue preciso entonces atraer a los escépticos y curiosos alrededor de las maravillas del cine mudo, y así ir cosechando nuevos admiradores y aglutinando aficionados. La necesidad de un órgano de difusión masiva del cine se hizo evidente.

La publicidad la podemos entender como un método persuasivo dirigido a influir la conducta de las personas. Su naturaleza es comunicativa. En el marco de un modelo económico de libre mercado, la publicidad es un instrumento económico utilizado por las empresas para promover la

\footnotetext{
${ }^{11}$ Nota ¿Pasará el cinematógrafo? por Atilano Pérez, en Olympia, julio de 1915.
} 
demanda de sus productos o servicios (CNICE, 2004). Los empresarios del cine se valdrían de una serie de estrategias comerciales para promover el gusto entre los bogotanos por el cine.

El primer paso se da el 17 de septiembre de 1908, día en que aparece el primer número de la revista Cinematógrafo con la orientación de Manuel Álvarez Jiménez. El investigador Hernando Martínez Pardo la postula como la primera revista de cine que se publicó en Colombia. Publicaciones posteriores de este período serán los órganos de publicidad de teatros o empresas de producción, distribución o exhibición (FPFC, p. 9).

Estos órganos de publicidad serán los vehículos de difusión del cine y serán los Di Doménico quienes contarían con los medios para poner en funcionamiento una imprenta dedicada a la distribución de un magazine cinematográfico, con una clara referencia a sus servicios. El Kine tenía terreno ganado en esta materia, pues había publicado ya en Barranquilla, Sincelejo y Bogotá desde el año anterior. En junio de 1915 los Di Doménico publican por primera vez la revista Olympia, cuyo valor por ejemplar es de 1 centavo, en formato periódico y con noticias de las hazañas de la empresa, artículos inspirados, colaboradores locales sobre cine, artes y actualidades y otros reproducidos de revistas extranjeras (Nieto y Rojas, 1992).

Olympia, revista cinematográfica ilustrada, es dirigida por Hernando Bernal y sacan por edición hasta 5 mil ejemplares (FPFC, p. 15). La Olympia al igual que la revista Películas luego, básicamente incluirían dentro de su contenido noticias sobre el séptimo arte en las principales capitales de cine del mundo, noticias sobre eventos relacionados con el cine en la ciudad o distintas actividades a llevarse a cabo dentro de las salas de cine por parte de los propietarios, anuncios de próximos estrenos, argumentos de las películas que se presentarían, cartas enviadas por lectores, cuentos y poemas de diversa índole temática, críticas de cine por parte de los pocos cinéfilos del momento y fotografías de las más deseadas actrices italianas o francesas, etc.

La configuración de una escena del cine en Bogotá ameritaba la progresiva conformación de una comunidad alrededor del cine, en virtud de la cual aparecerían roles tan importantes para su difusión como lo son los directores de las revistas, los periodistas y los cronistas. Roles cuya articulación permitiría hacer del cine cada vez más un acontecimiento social. Por aquella época existía la Asociación de Cronistas en Bogotá, cuyos cronistas acostumbraban asistir a los eventos y espectáculos con el fin de emitir una opinión sobre la calidad de las funciones, sus impresiones, etc. Prueba de esto es la nota que pasó la Asociación de Cronistas a las distintas empresas de empresarios públicos a través de la cual les pedían a los mismos reconocer el carné de cronista expedido por la corporación. La 
empresa de los Di Doménico por ejemplo, resolvería reconocer y aceptar el carnet de los cronistas en su salón, por lo que en lo sucesivo los cronistas y directores de periódicos a quienes hayan pasado en lista la Presidencia de la Asociación, tendrían derecho a pedir una boleta de entrada presentando su carné. En el Salón Olympia los Di Doménico dispusieron un empleado destinado específicamente para este fin ${ }^{12}$.

Los hermanos Di Doménico desde 1913 comienzan su entrega del Diario Colombiano, primeros ejemplos de crónica capitalina, un noticiero de imágenes en movimiento realizado en el país, filmado y procesado en película de cine (FPFC, p. 12).

En 1916 Películas reemplazaría a la Olympia como órgano difusor de la empresa de los Di Doménico (Nieto y Rojas, 1992). En 1919, Películas reinventaría su imagen y contenidos. Su objetivo, al igual que el de su predecesora, no era generar una ganancia extra o complementaria a la conseguida por cuenta de las funciones, sino estimular el interés de las personas por el cine, lo cual constituyó una estrategia de mercado muy efectiva ya que el solo precio de la revista era mínimo y su capacidad de atraer un público fue notable. Así lo demuestra una referencia expuesta en su segundo número publicado:

Sólo dos números han sido publicados de la Revista Películas en su nueva forma y ya las cartas venidas de las Agencias Cinematográficas son índice concreto y explícito de la acogida que ha tenido en todas partes... Confiamos en que nuestros Agentes nos secundarán en esta obra que nos hemos propuesto. A ellos más que a nadie, interesa el que la Revista sea leída en todas partes, pues ello ayudará a aumentar el número de espectadores. Además el ínfimo precio de cada número, permite que pueda ser comprada por todos. Nuestro deseo no es hacer de esta publicación una empresa financiera sino un medio de intensificar el amor y la admiración por la belleza y por el arte mudo. ${ }^{13}$

Películas tendría estrategias muy particulares para promover el gusto por el cine, por ejemplo concursos que se impulsaban desde la revista. Uno de ellos fue el concurso a la mejor composición o prosa sobre la célebre actriz del cine mudo Francesca Bertini, la italiana que por entonces se robaba todas las miradas de los caballeros en el globo. Sobre el concurso los organizadores resaltan:

\footnotetext{
${ }^{12}$ Nota La Asociación de Cronistas, en Revista Olympia p. 3, 28 de agosto de 1915.

${ }^{13}$ Nota El éxito de nuestra revista, en Películas p. 1, marzo de 1919.
} 


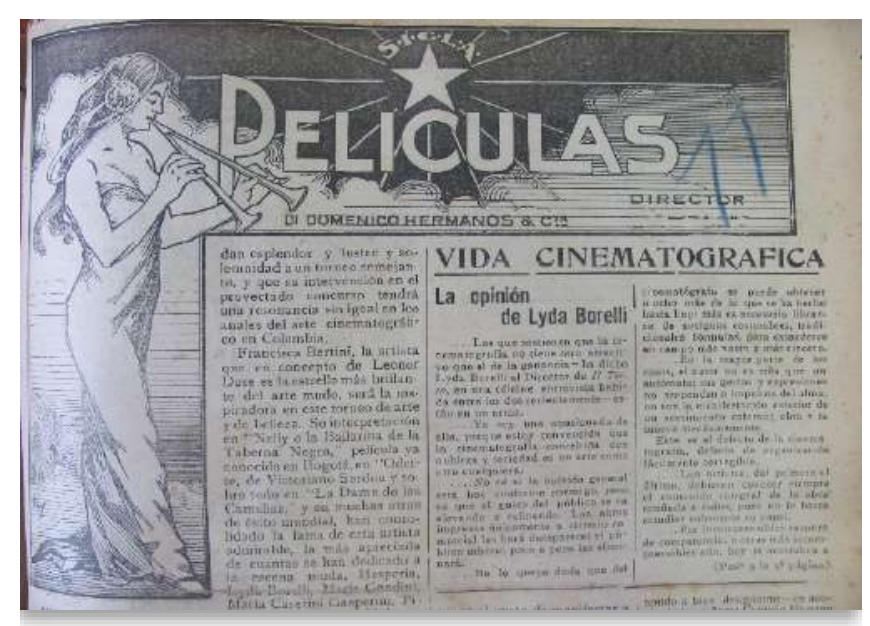

Fotografía 7: Portada revista Películas, 4 de noviembre de 1916.

La Dirección de Películas, al iniciar el concurso en cuestión, anhela insinuar entre nuestros intelectuales el gusto por el arte nuevo: que se piense que el cinematógrafo no es una diversión barata, para las clases pobres, sino también la culminación del arte escénico en su más moderna y adaptable forma. Hacemos pues un llamamiento a todos los amantes del arte cinematográfico para que tomen parte en el concurso ${ }^{14}$.

El 1 de mayo de 1924, es publicada por primera vez la revista Cine Colombia, que circularía periódicamente como organismo de difusión de las principales actividades de la empresa de los Acevedo (FPFC, p. 10). Cine Colombia publicaba las novelas de las películas de la Casa Cinematográfica Colombia (FPFC, p. 21).

Las estrategias publicitarias no se limitarían únicamente a revistas y magazines sobre cine. Los Di Doménico habrían de aprovechar el primer vuelo en avión que se hizo sobre Bogotá el 17 de agosto de 1919 durante la fiesta de la independencia: dispusieron que el piloto del avión lanzara sobre el cielo bogotano cientos de volantes alegóricos a la independencia y a sentimientos patrióticos, pero al mismo tiempo hiciera eco de la SICLA ${ }^{15}$. Para 1927, el interés por el cine logra posicionarlo dentro de los periódicos nacionales, para ese año El Tiempo trae por separado una página femenina, una página deportiva, una página automovilística, una página jurídica y una página cinematográfica (FPFC, p. 8).

\footnotetext{
${ }^{14}$ Nota Nuestro Concurso, en Películas, p. 1, 4 de noviembre de 1916.

${ }^{15}$ Volante SICLA primer vuelo de avión sobre Bogotá. Revista Películas No.125, agosto de 1919.
} 
El objetivo de estos esfuerzos sería dar a conocer los avances en materia cinematográfica y crear poco a poco una comunidad alrededor del séptimo arte, modelando así un ambiente y un circuito cinematográfico en la ciudad por medio del cual se irían tejiendo vínculos entre la sociedad y el cine. La publicidad sería fundamental en esta empresa, ya que tendería puentes entre un público aún muy conservador y parroquial y un cine mayoritariamente extranjero en realidades muy disimiles.

\section{El ímpetu de la experiencia del cine de los bogotanos}

Al principio era la única distracción popular que existía y eso que la boleta para el cine era carísima, pero valía sus veinte centavos (Arciniegas, 1992, p. 9).

El cine modificó la manera en que los bogotanos experimentaban el ocio y el esparcimiento cultural. Paulatinamente, ir a cine se convirtió en una opción atractiva entre los bogotanos para ocupar ese universo que llamamos "tiempo libre".

La actividad del entretenimiento registró un cambio esencial hacia el siglo XX, cuando salió del reino del hogar y pasó del ambiente privado o muy reducido, a lo público. Desplazó el entretenimiento privado ejecutado en el seno de la familia y que incluía veladas lírico-musicales, sermones patriarcales, lecciones de abnegación maternal y rueda de chismes (Ávila y López, 2006).

El impacto del cine como espectáculo en las interacciones sociales del ocio no obstante, no se puede entender únicamente desde la relación espectador-película, había muchos más componentes en juego en el acto de ver cine, como tampoco se puede entender dicho acto simplemente como el agregado de varios componentes circundantes y desarticulados.

El concepto de experiencia de cine permitirá comprender cómo "ir a ver cine" articula una multiplicidad de elementos que carecen de sentido por sí solos a menos de que estén ligados a la actividad propia de ver una película, elementos que se agotan por sí solos fuera del acto del cine que es su eje articulador. Entenderemos la experiencia del cine como el conjunto de prácticas, costumbres y hábitos que rodean el acto singular de ver una película y que están directa o indirectamente relacionados con esta acción. Estos elementos a primera vista accesorios y agregados, son parte fundamental para dotar de sentido a la experiencia cinematográfica del momento.

La experiencia del cine comprende en principio a las personas en cuya compañía el espectador ve la película porque son parte de su entorno y con quienes interactúa, siendo el filme el telón de fondo de esta relación. 
Se tenía la plena consciencia al asistir al teatro, que no sólo se verían las caras con otros desconocidos, sino que departirían con ellos alrededor del filme, y eso no era algo circunstancial de la experiencia sino parte constitutiva de la misma. Vivir el cine en ese momento era vivir el cine con otros, una experiencia más que individual, colectiva: el cine como espacio de encuentro.

La llegada del cine a Bogotá supuso una ruptura de fronteras sociales con su oferta de entretenimiento accesible para más personas, fue una alternativa real (frente a las corridas de toros, por ejemplo) pues no dependía de temporadas especiales, se podía ir cualquier día en uno de los horarios posibles (Saldarriaga, 2000); inclusive, el Olympia tenía un horario en el que las boletas eran más baratas para que los obreros pudieran asistir (IDARTES, 2012).

El crisol de clases sociales encontraría una válvula de escape en estos grandes salones, donde la clase distinguida bogotana apelaría al uso de sus ventajas relativas y códigos culturales para poner de manifiesto la distinción social. Por ejemplo, en los tiempos en que se veía cine en el salón del Bosque los que pagaban menos, veían la película a la intemperie (IDARTES, 2012). En el Olympia la pantalla (la sábana) estaba extendida en el centro del salón, por lo que había una diferenciación social entre los que podían ver la película de frente (quienes pagaban más) y quienes veían la proyección detrás de la pantalla (quienes pagaban menos), donde aparecía la imagen al revés. Al ser cine mudo con las explicaciones de la trama en letreros y títulos, las personas que veían la proyección detrás de la sábana se las ingeniaban para disfrutar la función tanto como sus vecinos del frente, y es por eso que recurrían a espejos que llevaban al salón para poder leer los letreros o contrataban personas habilidosas que podían leer los letreros al revés (Nieto y Rojas, 1992). Así pues, a pesar de albergar a diferentes clases sociales, dentro de las salas se establecían igualmente micro-dinámicas de distinción social.

La empresa de los Di Doménico estuvo siempre a la vanguardia de la oferta de entretenimiento para sus clientes, entre quienes se encontraba una gran cantidad de niños y niñas que asistían con sus padres, de ahí que la empresa dirigiera varios esfuerzos a complacer también a los más chicos, después de todo un auténtico templo del entretenimiento debe tener en cuenta los gustos y caprichos de todos sus asistentes y estar presto a satisfacerlos. El Olympia abrió un concurso de pintura para niños con el fin de hacerles más amena la matiné de los domingos. Los motivos de las pinturas eran libres y debían hacerse en vidrios pequeños y con tinta china (que serían suministrados en la oficina del salón), para así exhibir los mejores en el telón en los intermedios de los matinés. Todos los domingos 
se cerraría un concurso y sólo se exhibirían aquellos traídos durante la semana. El dibujo que haya sido considerado por el jurado calificador como el mejor, llevaba la fotografía de su autor o autora. Cada dibujo hecho en el vidrio debía tener al pie su leyenda o explicación en letra clara y pequeña. Cualquier instrucción en particular sobre la realización de los dibujos podía ser consultada en la oficina de la empresa Di Doménico (carrera $7^{\mathrm{a}}$ número 547).

Expresarían los empresarios: “Queremos de este modo interesar a los niños de Bogotá, hacerles pasar unas horas agradables los domingos" 16 . Concursos como estos generaron todo tipo de expectativas y entusiasmo entre los niños, quienes participaron de manera activa con sus dibujos, como lo informa una nota de Películas, la que indica que el último domingo fue premiado por su dibujo el joven Julio Galviz con una bella y lujosa cartera. Mientras que para el resto del público se rifó un reloj de pulsera que se lo ganó el joven Manuel María Vargas, a quien le correspondía la boleta número 371. La empresa anunciaría la rifa de bellos objetos para los próximos matinés ${ }^{17}$.

El concurso de dibujos para niños y las rifas de objetos no serían las únicas actividades de entretenimiento que conformarían la experiencia del cine, también encontramos concursos destinados para los adultos, especialmente para los caballeros. En su número de octubre de 1915, Olympia anuncia la apertura de un concurso en el que se invitaba a todos los caballeros asistentes del teatro Olympia, para que aportasen su voto por escrito y en cubierta cerrada para escoger a la asistente más bella, esto con el objeto de una serie de funciones elegantes que la empresa Di Doménico organizaría para los días jueves de cada semana. La dama con la mayor cantidad de votos sería obsequiada con una "regia" función de gala, en la cual se le dispondría de manera especial el palco de la presidencia, y se proyectaría su retrato en el telón del cinematógrafo, además de ser publicado también en una nueva sección de Olympia que se llamaría Galería de Bellezas ${ }^{18}$.

\footnotetext{
${ }^{16}$ Nota El concurso para niños, en revista Películas, número 121, abril de 1919.

${ }^{17}$ Ver en revista Películas, número 121, abril de 1919.

${ }^{18}$ Nota Novedad en el Salón Olympia, en revista Olympia, p. 1, 2 de octubre de 1915.
} 


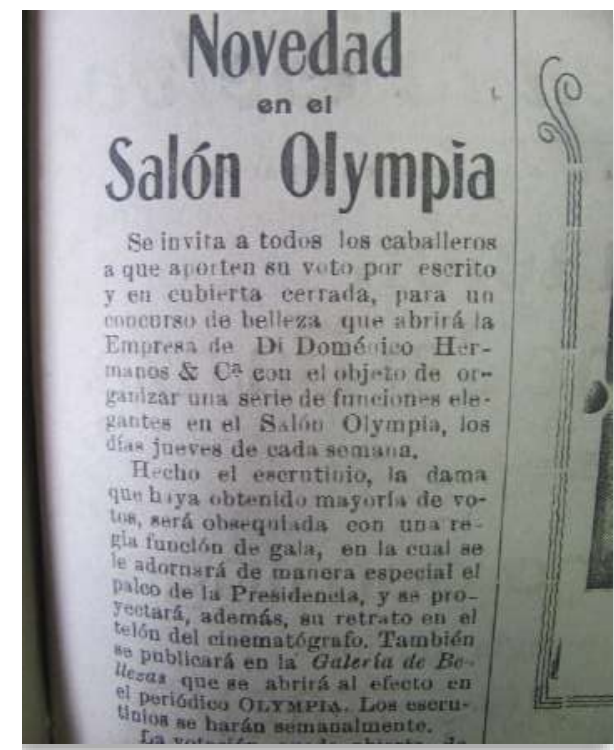

Fotografía 8: Concurso para caballeros en el Salón Olympia.

En revista Películas, 2 de octubre de 1915.

Las rifas y concursos no serían exclusividad del salón Olympia, otros salones y teatros que exhibían cine debían adaptarse a los pasos agigantados que daba el Olympia, y conquistar el favor de un mayor público, ampliando el tipo experiencia de cine que ofrecían. Así lo dejaría ver un anuncio publicitario de El Tiempo en febrero de 1927, donde se anuncia la rifa de una bella muñeca entre los asistentes que concurran a la función del sábado en el teatro Caldas de Chapinero ${ }^{19}$.

La asistencia de cronistas a las funciones de cine era habitual. Sus relatos en revistas narraban a la gente no sólo sus percepciones de los filmes que habían visto, sino también las impresiones y emociones que la experiencia del cine despertaba en ellos. Sus relatos constituirán una valiosa fuente de información pues suponen una "ventana" en el tiempo a través de la cual podemos acceder a las peculiaridades y particularidades propias de la idiosincrasia bogotana alrededor de la experiencia del cine.

Tic-Tac, un cronista caracterizado por un sentido de humor mordaz, escribe en 1919 una crónica para la revista Películas, titulada "La 'velada' de anoche" ${ }^{\prime 20}$ donde relata sus impresiones sobre una velada de cine en el Olympia. De su relato quisiéramos destacar la manera en que describe el

\footnotetext{
${ }^{19}$ Ver en El Tiempo, pg. 7, 19 de febrero de 1927.

${ }^{20}$ Ver en revista Películas, número 123, junio de 1919.
} 
comportamiento del público durante la función, describiéndolo como todo menos pasivo; veremos un público que confronta, que reacciona, un público que replica, que se expresa, un público que está en constante conversación con quienes proyectan el cine, lo cual es muestra no sólo del interés del público por su entretenimiento, sino que explica la manera en que durante este período el dinamismo del público era pieza clave en la consumación de la experiencia del cine. Su relato nos permite hacernos una imagen general de las prácticas, hábitos y costumbres que daban forma a la experiencia del cine de un espectador.

Señala que Di Doménico proyectó una película de la actriz infantil María Osbourne, titulada "Conquistando a la abuelita", comenta:

Confieso que las cintas de esta niña son más adecuadas para matinée de pequeñuelos que para funciones de gente "criada". A una travesura de la Osbourne prefiero una contorsión espasmódica de la Bertini o una languidez erótica de Don Casto.

En su opinión esta no era una película adecuada para un público adulto y experimentado que deseaba una diversión menos infantil, de ahí la palabra "criada", haciendo alusión a un público ya mayor que no está para historias cándidas.

Hubo quienes no le pusieron ni la más mínima atención a la película. El amor también tendría su espacio durante las funciones de cine. TicTac advertiría en su relato, que a lo largo de la proyección una pareja de enamorados aprovechaba la oscuridad de la sala, creyendo que nadie los vería, para hacer demostraciones de amor:

Hay enamorados que van al cine no a ver la película sino a hacerlas; no a estar en la función sino a darla. Y se toman ciertas libertades... Y piensan que en público se puede hacer lo que se hace en privado y que, apagadas las luces, no queda quien les mire. Y se equivocan. El público es como los gatos: ven en la sombra.

A continuación, ante esa errada lectura del público asistente de esa noche por parte del empresario, él se apropia primero de la situación y asume una respuesta efectiva, es así como interviene en rechazo al filme:

En el primer acto, el público no estuvo bien con el film y empezó el meneo y la chifladura. El empresario creyó que el público pateaba a los músicos y pasó a la orquesta a pedir que cambiaran el vals. Uno de los músicos, herido en su amor de artista le dice a Doménico: La calentura está en la sábana, es decir: lo que el público está pateando es la cinta. 
Una vez acabada la película de la "cachifa" Osbourne (en palabras de Tic-Tac) a las diez y media de la noche, el empresario proyecta un rollo de Pathé Journal como intermedio para una pousse-café, pero esto al público nuevamente le irritaría:

Y este público necio empieza a armar bronca y pedir otra cosa. Entonces el empresario -quizás por desquite- resuelve enflautarnos a esas horas la cinta del "Caballo Policía"...Y poco a poco la función se va haciendo pesada y la gente se va desangrando. Los pobres músicos tienen que seguir amenizando el espectáculo con su escogido repertorio.

La velada que narra Tic-Tac no se puede pensar como una excepción a la regla o un hecho extraordinario, sino como una situación bastante frecuente en los teatros de cine de la época. Escribe un asistente indignado una carta para El Tiempo en 1914:

Verdaderamente repugnante es lo que está pasando en las representaciones cinematográficas del Salón Olympia. El Público no guarda la compostura, pues se ha figurado que aquello es un circo de toros o una gallera. Lo ocurrido la noche del domingo es verdaderamente vergonzoso: el pataleo, el compás de la música llevado con los tacones y las varitas de nuestros filipichines tropicales, los chistes flojos o de corrillo, la falta de civilidad para con las damas, y la cantidad de humo con la que se envicia el ambiente... ${ }^{21}$

Tic-Tac correría con suerte que en aquella velada a la que asistió, la bronca del público con la película no terminó en una reyerta de mayores proporciones. Los empresarios de los espectáculos públicos sabían de los "desentables" (como se llamaba en la costa atlántica a las protestas del público) que se presentaban con cierta frecuencia por los más diversos motivos. Los hijos de Francesco Di Doménico recuerdan que les destruían el teatro el lunes y el miércoles estaba funcionando otra vez; tenían un carpintero de planta, Domingo Pedraza, que en un momento arreglaba el salón y claro, con la platea reducida, pero se daba la función que se había prometido. Las mujeres de la casa se ponían a coser esa lona enorme, de varios metros, cuando también había que reparar el telón (Nieto y Rojas, 1992).

Los desentables como se suelen llamar estos altercados que desembocan en cierta violencia menor, parecían consecuencia necesaria y

\footnotetext{
${ }^{21}$ Noticia En el Olympia en El Tiempo, 2 de junio de 1914.
} 
expresión de la experiencia del cine en aquel momento, que a diferencia de hoy, era un comportamiento frecuente entre los asistentes que no tenían reparo en protestar ante el filme proyectado, alzar a viva voz sus querellas e incluso llegar a generar daños al teatro o enfrentarse con otros asistentes si los ánimos se caldeaban, de una u otra forma el cine era el espectador de lo que sus espectadores hacían, esa sí que era la verdadera función.

Uno de los desentables más recordados tuvo lugar en el salón Olympia, donde al término de la proyección de la película Noche de angustia el empresario decidió pasar la película cómica titulada El método Toribio para regenerar la humanidad, la cual no fue del agrado del público que comenzó a hacerse escuchar mediante gritos a la pantalla. El empresario decidió hacer caso omiso a los bramidos del público. Lo que ocurriría en seguida así lo narra El Tiempo del 8 de abril de 191722:

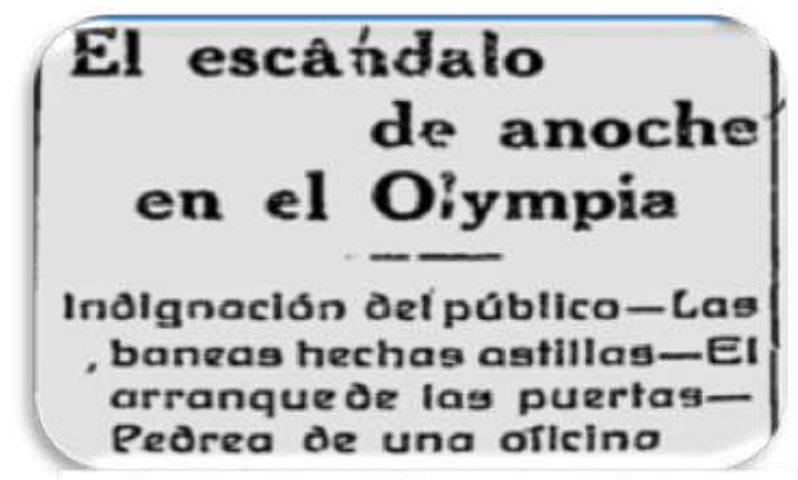

Fotografía 9: Título de noticia en El Tiempo. 8 de abril de 1917.

El público resolvió pasar de los gritos a las vías de hecho, y en medio de la oscuridad comenzó a romper las bancas y las sillas. El operador al ver el carácter grave que asumía la protesta, encendió la luz pero el público continuó en su tarea, quebrando los asientos y arrojando los pedazos de estos contra la pared y los palcos, en donde se encuentra el aparato. Cuando ya habían roto muchas bancas, sacaron las restantes a la calle, destrozaron el telón y el escenario, destruyeron las puertas y ventanas y empezaron a arrojar piedras contra las bombillas de la luz. En tales momentos llegó un piquete de cerca de 200 agentes de policía, armados de Mausser y se impuso a la multitud, la que se retiró echando abajos al Olympia y a los señores Di Doménico, a apedrear la oficina de estos, situada en la Avenida de la República. Principiaba a realizar su intento cuando otro piquete que bajó por la calle 18 detuvo a los mitingueros.

\footnotetext{
${ }^{22}$ Noticia El escándalo de anoche en el Olympia, en El Tiempo p. 3, 8 de abril de 1917.
} 
De esa noche no quedaron sino los daños materiales, el rechazo de la prensa a esta violencia injustificada, y varias damas que tuvieron que presenciar el hecho y que pudieron salir heridas a causa de las astillas que iban y venían, y muchos caballeros "descalabrados".

La experiencia del cine engloba desde luego todos estos pataleos, ruidos y hasta tropeles que el público efectúa para mandar un mensaje al empresario sobre el tipo de películas y el contenido que desean ver, algo que como sabemos no ocurre hoy en día en el ambiente impersonal de la sala multiplex, las personas son conscientes que van "exclusivamente" a ver una película, que ya previamente han definido y sobre la cual la cadena de cine encargada ha dispuesto con un horario. Hoy sería absurdo llegar a una sala de cine y atenerse a lo que el empresario desee proyectar (algo que también tenía que ver con la oferta de filmes en aquella época), deleitarse o aborrecer la música en vivo de la orquesta, tomarse un tiempo de pausa para tomar algo y hablar con otras personas, participar de rifas con los demás asistentes, que los niños hicieran dibujos para proyectar en la pantalla, que las mujeres participaran de concursos de belleza entre ellas y que les obsequiaran flores en galas especiales, pero sobretodo resultaría insólito hoy en día pararse de la silla y quejarse a viva voz de la proyección, con la "esperanza" de que el empresario encargado decida cambiar la película.

Sin embargo, estos eran los factores que constituían la experiencia del cine a comienzos de siglo $\mathrm{XX}$ y son precisamente los que la diferencian de experiencias de cine venideras. La experiencia del cine durante la primera edad del cine en Bogotá se caracterizó por su dinamismo, en lo absoluto estática, suponía un constante diálogo entre el espectador y los demás espectadores, entre el públicoy la orquesta, entreel público, los proyeccionistas y empresarios; y todo confluía alrededor de una práctica tan simple como lo es sentarse en una silla y observar una película. La experiencia del cine en esta primera edad del cine en Bogotá estuvo atravesada por lo colectivo, por las múltiples interacciones tejidas alrededor de la proyección.

\section{El cine y la noche bogotana}

"La Avenida de la República se anima en la noche con el desfile de los que van camino al cine..." Carlos Torres Durán ${ }^{23}$

El cine se posicionó vertiginosamente como un espectáculo dilecto entre el público bogotano para quienes se convirtió en una alternativa preferente para utilizar su tiempo libre, dándole un nuevo sentido a, como veremos en el relato del cronista, la noche. Así lo describe Tic-Tac:

\footnotetext{
${ }^{23}$ Crónica Al margen del cine, de Carlos Torres Durán, en Películas, número 126, septiembre de 1919.
} 
Yo voy al cine por pasar el rato, no por ver lo que pasa en el telón. Por matar el tiempo, no por informarme de los hechos del cine. El convencionalismo del cine me estomaga... pero en el cine mato media noche. Oigo música. Veo la gente. Pululo por entre mis conciudadanos y conciudadanas. Y a la hora de la cita duermo como un congresista.

Carlos Torres Mejía escribe una crónica publicada en Películas y la revista Cromos en 1919 donde también relataría una noche de cine:

En las noches en que el Salón Olympia abre de par en par sus puertas anchurosas y se dispone a hacer pasar por la pantalla al compás de la música, esa cosa alada, ligera, luminosa, que es una película cinematográfica... el respetable público que va inundando el teatro poco a poco, que va llenando el salón profundamente con su mescolanza de tipos, siempre nueva y siempre pintoresca. ${ }^{24}$

Dos servicios fueron fundamentales para ir sacando de a poco la noche bogotana de la experiencia familiar en las casas: el alumbrado público y el tranvía. En 1889 se creó la compañía denominada The Bogotá Electric Light Company, para el suministro de alumbrado público por electricidad. El alumbrado público sería, durante años, el uso principal de la energía, la instalación domiciliaria fue después. En 1904 se constituiría la Compañía de Energía Eléctrica de Bogotá (Saldarriaga, 2000).

Si bien a comienzos de siglo el tranvía era de tracción animal (mulas), operaron así hasta 1910, cuando se electrificó la red y se amplió su cobertura por parte de la The Bogotá Railway Company, pues anteriormente sólo existían dos líneas que conectaban la Plaza de Bolívar con Chapinero y la plaza con el occidente de la ciudad, hasta la Estación de la Sabana: "Los tranvías pasaban atestados de gentes. Las personas que van a pie, caminan de prisa, de prisa, de prisa. Las siluetas de las mujeres que llevan abrigos amplios y sombreros lindos, se deslizan rápidamente (Saldarriaga, 2000)" ${ }^{25}$

En el repertorio de la vida urbana en Bogotá en las postrimerías del siglo XIX, figuran algunos de los estereotipos de la cultura bogotana tales como el "cachac", las "beatas", las veladas literarias y musicales, las tertulias domésticas, los paseos campestres, el chocolate santafereño, los aguinaldos. En 1900, los entierros de personas notables fueron curiosamente uno de esos eventos que atrajo la atención ciudadana (Saldarriaga, 2000).

\footnotetext{
${ }^{24}$ Crónica Al margen del cine, de Carlos Torres Durán, en revista Películas, número 126, septiembre de 1919.

${ }^{25}$ Ibídem.
} 
Las élites bogotanas tenían como actividad cultural principal el teatro, que ocurría en los dos teatros de la ciudad: el Municipal y el Colón. Este primero fue abierto a manifestaciones diversas de teatro, música, veladas políticas y literarias. Los bogotanos más pobres, por su parte, no tendrían muchas más opciones de entretenimiento. El consumo de la chicha fue uno de los placeres del pueblo, muy a pesar de las autoridades y la gente de bien. A finales del siglo XIX existían unas 700 chicherías por toda la ciudad, una de las pocas herencias de tradición indígena que sobrevivieron a la colonia (Saldarriaga, 2000).

El cine aparecía como una opción de esparcimiento novedosa, que abría el paso a la noche y la llenaba de una sensación de posibilidad: la noche como espacio en el cual una variedad de actividades podían tener lugar, siendo el cine el eje sobre el cual muchas de ellas giraban; como espacio social referido "afuera" de la casa, en contraposición a la noche tradicional privada a puerta cerrada en el seno familiar.

La importancia del cine para las noches de ocio bogotanas la resumiría Tic-Tac con la siguiente frase:

A las 3 de la mañana, después de haber visto a Juance, en traje de frac, llego a mi posada y tiro sobre la almohada la cabeza llena de pensamientos recién cogidos, morados y amarillos. Con otra película que hubieran dado en el Olympia, habría llegado a mi cuchitril a las siete de la mañana. Es decir habría llegado al día siguiente. ${ }^{26}$

\section{La organización institucional alrededor del cine}

Dos son los fundamentos o causas que impulsan a la hostilidad de la acción oficial: primero, la moralidad, y segundo, la creencia de que el cine es un negocio fabuloso y de que hay tela para cortar... (revista Películas). ${ }^{27}$

La rápida expansión del cine forzó a las autoridades públicas a disponer de un cuadro burocrático que regulara las diferentes dinámicas que emergieron alrededor de las proyecciones.

La Alcaldía de Bogotá ofició en julio de 1914 al Inspector $7^{\text {}}$ municipal para que en el salón Olympia hiciera cumplir las disposiciones de la Prefectura, con el fin de que durante las funciones se mantenga la salida expedita y libre de todo estorbo a los espectadores, para prevenir

\footnotetext{
${ }^{26}$ Crónica Al margen del cine, de Carlos Torres Durán, en Películas, número 126, septiembre de 1919.

${ }^{27}$ Nota Los apóstoles de la farsa, en Películas número 121, abril de 1919.
} 
un accidente ${ }^{28}$. Así mismo con respecto a los "desentables", la respuesta no se hizo esperar. En 1919 la Guardia de Cundinamarca, dirigida bajo el mandato directo del Gobernador, comienza a prestar sus servicios en el salón Olympia. Fue un cuerpo organizado de hombres dispuestos para garantizar el orden en caso de un exabrupto ${ }^{29}$.

Las respuestas efectivas por parte de las autoridades ante los desmanes provocados dentro de las salas de cine fueron en muchas ocasiones implacables. Por ejemplo, en alguna oportunidad los Di Doménico se vieron forzados a cancelar su función del sábado por orden de la autoridad, debido a un altercado que tuvo lugar dentro del Olympia. Las autoridades se llevaron al individuo provocador, pero aun así ordenaron cancelar la función:

La autoridad justamente alarmada, prohibió abrir las puertas de nuestro teatro, y es probable que el causante de este acto, que perjudicó tanto a la Empresa como a todo su tren de empleados, haya sido castigado por la misma autoridad que se vio obligada a proceder contra nosotros sin que de nuestra parte hubiera siquiera un acto censurable. $^{30}$

Se buscó desmantelar los cines "de garaje" o "ilegales" que estaban proliferando en la ciudad y que no contaban con un aval de la autoridad municipal para su funcionamiento. Un ejemplo de esto es la prohibición del cine anunciador de San Francisco en 1927. El inspector primero municipal de Bogotá dictó la prohibición del funcionamiento del cine anunciador que se estableció en el último piso del Edificio Zapata. La razón para hacerlo es que sus dueños lo pusieron a funcionar sin haber adquirido antes la correspondientelicencia dela autoridad municipal correspondiente, sumado a que concurrieron multitud de particulares a quejarse por los perjuicios que se causaban por la aglomeración de personas que se formaba al frente del cine por las noches, y a donde acudían "hombres de procedimientos sospechosos" ${ }^{\prime 31}$. La resolución también incluía hacer efectivo en el menor tiempo posible la retirada de los avisos instalados en uno de los balcones del edificio y cuyo aspecto perjudicaba la estética de la calle.

Frente los problemas que provocó la reventa de boletas y el sobrecupo dentro de los teatros, la autoridad municipal fijó oficialmente el cupo del salón Olympia. No podría excederse de estos topes: salón principal centro:

\footnotetext{
${ }^{28}$ Noticia La Gobernación y el Salón Olympia, en El Tiempo, 3 de junio de 1914.

${ }^{29}$ Nota Guardia de Cundinamarca, en Películas, número 124, julio de 1919.

${ }^{30}$ Nota Lo del Sábado, en Olympia, 21 de agosto de 1915.

${ }^{31}$ Noticia Se prohíbe el cine anunciador de San Francisco, en El Tiempo, p. 4, 15 de marzo de 1927.
} 
1011, lateral derecho: 223, 36 palcos de salón: 216, 8 palcos altos: 48, 1 palco chico: 4. galería antes de la barrera: 288, detrás: 200, lateral derecho: 105, lateral izquierdo: 105, escenario: 725, 12 palcos: 72, 2 palcos: 28, 1 palco: 12 . Total: 3,038 personas (Nieto y Rojas, 1992).

La regulación abarcaría también los horarios en los cuales las películas se presentarían para evitar alteraciones o disgustos por parte del público. Así se puede ver en esta nota sobre el llamado de atención que realiza el Inspector $7^{\circ}$ Municipal a la empresa SICLA por la falta de cumplimiento del Decreto Oficial que fija la hora en que deben comenzarse las funciones:

Si alguna vez se ha retardado la hora fijada, es decir, la de la licencia, se debió quizá a casos fortuitos como daño del aparato u otros en los cuales la Empresa no tiene la culpa. Además si no nos engañamos, hay un Inspector de Espectáculos que regulariza esto, y nunca nos ha llamado la atención ${ }^{32}$

La intervención del Estado sobre el negocio del cine se tornaría cada vez más rigurosa, afectando directamente al negocio y su rentabilidad. El acuerdo No.1 del Concejo de Bogotá en 1918 impone una renta del 10\% sobre todos los espectáculos públicos, incluyendo el cine, para el Fondo de los Pobres (FPFC, p. 3). Además de los derechos de importación de las películas, existían los "derechos de permiso", figura con la cual los concejos municipales alimentaban sus menguadas arcas. Los primeros subían constantemente mientras que los segundos eran arbitrariamente fijados (Nieto y Rojas, 1992). Como si esto fuera poco, en 1920 se decreta en Bogotá el cobro de un impuesto justificado en la inmoralidad imperante $y$ el hecho de que el cine acarrea funestas consecuencias para la juventud (FPFC, p. 6). Sin embargo, el "golpe" más duro a la empresa del cine en Bogotá se había asestado 6 años antes.

En 1914 se crea la Junta de Censura de Cinematógrafos en Bogotá. De conformidad con lo dispuesto por el decreto número 104 de la Gobernación de Cundinamarca, quedó constituida la Junta de Censura, la cual nombró a don Lino de Pombo como presidente y a don Rafael Pardo de Francisco como secretario. Se nombró de igual forma una comisión redactora de los estatutos y se distribuyó el trabajo de una manera conveniente entre los miembros principales y suplentes:

La autoridad negará todo permiso cuando el repertorio de la Empresa respectiva o las nuevas películas que se introduzcan sean inmorales, por resultar de ellas la halagadora exhibición o el triunfo escandaloso

\footnotetext{
${ }^{32}$ Ver La hora de las funciones, en Películas, número 120, marzo de 1919.
} 
del crimen, o el vicio o la enseñanza del robo o por poner en ridículo a los Ministros o símbolos y prácticas religiosas y cuando representen escenas contrarias a la decencia y las buenas costumbres de la civilización cristiana ${ }^{33}$.

Un doble filtro se imponía frente a las películas. Por un lado, la Junta de Censura que podía negarle el paso a alguna película que considerase inmoral, pero tambiénla Gobernación deCundinamarca tenía la competencia de quitarle el pase a una película, aun cuando la Junta de Censura ya la hubiese aprobado. La censura departamental era muy estricta, por ejemplo, respecto a los besos que debían ser muy rápidos, ya que los lentos no se admitían (Nieto y Rojas, 1992).

Notardan en aparecer ciertos "protectores" dela moral pública, quienes desde el anonimato realizan acusaciones ante los entes competentes sobre la inmoralidad de las películas que se proyectan y su carácter desestabilizador de los valores y buenas costumbres de la sociedad bogotana:

Por insinuación de un caballero, la Gobernación se ha dirigido a la Junta de Censura a fin de que se revise el pase dado a 'Amazona Macabra' pues aquel desconocido caballero ha dicho que es inmoral... ${ }^{34}$

La preocupación de los empresarios sería evidente y su respuesta inmediata. Trasladarían su disputa con la institucionalidad a la esfera pública, recurriendo a su instrumento de difusión de información (revistas de cine), donde harían expresa su inconformidad por las decisiones arbitrarias de las instituciones encargadas de la regulación del cine. Los Di Doménico expresarían su indignación en la revista Películas, sobre todo por la prohibición de la gobernación a algunas cintas, lo que traía perjuicios económicos a las empresas cinematográficas:

Las Empresas en adelante, con esta nueva medida, están expuestas a cerrar los salones, porque el público ya no quiere ver sino cintas modernas, de arte, dramas reales, corrientes en cualquier parte del mundo. Ya se comprenderá la situación que se ha creado a las Empresas, pues comprada una cinta en Europa, si no la dejan dar, se perderán cantidades de dinero, no insignificantes, pues una cinta de arte alcanza a valer a veces hasta cinco mil dollars ${ }^{35}$

\footnotetext{
${ }^{33}$ Noticia Censura de Cinematógrafos, en El Tiempo, 25 de mayo de 1914.

${ }^{34}$ Ver Casos y Cosas, en Películas, número 120, marzo de 1919.

${ }^{35}$ Ver La Junta de Censura y la Gobernación, en Películas, número 119, enero de 1919.
} 
Durante este periodo será evidente la fricción entre los empresarios del cine y las autoridades públicas por la regulación del espectáculo cinematográfico, lo cual queda bien reflejado en esta nota de rechazo en Películas:

La actitud recientemente tomada por ciertos Concejos Municipales (Cali, por ejemplo), el cual aprobó un acuerdo para aumentar los derechos del cine a cantidades fabulosas; las tendencias de marcada hostilidad determinadas por Juntas de Censura de diversas partes; las trabas puestas por las entidades oficiales, negando el pase ya concedido por la Censura a las cintas, y muchos otros hechos significativos de una incomprensión lamentable del Arte Mudo, de sus conveniencias como espectáculo... ${ }^{36}$

Las pérdidas para los empresarios eran considerables. Tenían que luchar contra un aparato institucional que tenía como principios orientadores una férrea defensa de los valores y costumbres tradicionales, fuertemente ligadas a las creencias religiosas del cristianismo. La acción institucional amparada en la ley fijaba como ilegal el hecho de proyectar películas con contenido percibido como inmoral. El análisis de Howard Becker sobre la desviación es pertinente para comprender esta situación.

Afirma Becker que las normas, en este caso los decretos y acuerdos que reglamentan la censura de las películas, son reglas de comportamiento establecidas por grupos sociales. La infracción de dicha reglainmediatamente colocará sobre el infractor la etiqueta de desviado, lo cual trae asociados costos sociales, económicos y políticos. Quien fija las normas fija la conducta desviada (Becker, 2009). En ese sentido, quien ofrece y quien consume un cine inmoral, es un inmoral en su persona, un desviado de la sociedad.

En consecuencia, los acuerdos y decretos que reglamentaban la censura en Bogotá, siguiendo a Becker, fueron el producto de un conflicto político en el que un grupo social de poder, movilizó los recursos a su disposición para ejercer presión en determinadas esferas del poder público para generar la norma mejor adecuada a sus intereses, produciendo implícitamente la etiqueta del desviado. Pues como respondería Películas a una mujer identificada con el seudónimo de Pepita, a una de sus cartas con relación al tema de la censura:

Tiene usted razón. La moralidad de las cintas tiene íntima conexión con la moralidad de quien las ve. La vida se debe mostrar tal como es, y la farsa en el arte como en la vida es más inmoral que todo. Reconocemos que usted es una señorita inteligente y civilizada ${ }^{37}$

\footnotetext{
${ }^{36}$ Ver Los apóstoles de la farsa, en Películas, número 121, abril de 1919.

${ }^{37}$ Ver Correo de los Curiosos, en Películas, diciembre de 1916.
} 


\section{Conclusiones}

La primera edad del cine en Bogotá da cuenta del advenimiento del cine a la ciudad y su incontenible tránsito para erigirse en un espectáculo central del ocio capitalino. Fue un proceso acelerado del cual participaron diferentes actores, pero entre los cuales hay que resaltar el papel del empresario del cine. No sólo desarrollaron toda la infraestructura correspondiente asociada a la proyección del cine, sino que cada vez fue más evidente su esfuerzo por hacer de las salas de cine, auténticos templos del entretenimiento en donde cada detalle buscaba expandir la experiencia cinematográfica del espectador a través de elementos conexos al filme mismo. Con base en estos elementos, propusimos el concepto de experiencia del cine como aquella que no se agota en la relación cerrada de espectador-filme, sino que al contrario se encontraba mediada por una serie de prácticas y hábitos alrededor del acto cinematográfico que dotaban de sentido la experiencia misma, caracterizada fundamentalmente por la presencia de "unos otros"(experiencia colectiva) con quienes se veía la película.

De manera simultánea el empresariado del cine se dio a la tarea de tejer un medio cinematográfico en la ciudad que permitiese ir formando poco a poco una base de espectadores (no tanto una comunidad especializada en torno al cine) y en ello tuvo un papel significativo el medio escrito a través de sus revistas de cine, sin contar además todas las actividades y concursos asociados a sus teatros con los que conseguían conectarse con las personas. Finalmente, y en respuesta precisamente a la creciente popularidad del cine y su trepidante expansión, se vio necesario por parte de la institucionalidad formal disponer de una estructura burocrática para la regulación de diferentes dinámicas surgidas alrededor de las proyecciones. Justamente, fue por esa vía que se buscó regular también el contenido de las películas por su supuesta transgresión de una moral pública, confrontando así a un bien establecido círculo empresarial del cine con un negocio floreciente y una conservadora elite capitalina que desde su incidencia en el aparato institucional, buscaba neutralizar el avance del cine como erosionador de unas "buenas costumbres". Futuras investigaciones deberían dar cuenta de la manera en que el cine en Bogotá significó, y en qué medida, un cuestionamiento a los órdenes de sentido imperantes de su momento. 


\section{Referencias bibliográficas}

Libro:

Alcaldía Mayor de Bogotá, IDARTES. (2012). Bogotá fílmica: ensayos sobre cine y patrimonio. Bogotá: Subdirección Imprenta Distrital.

Antongini, T. (1981). Los escritores frente al cine. Madrid: Editorial Fundamentos.

Ávila, J., \& López, J. (2006). Salas de cine. Bogotá: Alcaldía Mayor de Bogotá.

Becker, H. (2009). Outsiders: hacia una sociología de la desviación. Buenos Aires: Siglo Veintiuno Editores.

Chaparro, H. (s.f). Cine colombiano 1915-1933: La historia, el melodrama y su histeria.

Nieto, J., \& Rojas, D. (1992). Tiempos del Olympia. Santa Fe de Bogotá: Fundación Patrimonio Fílmico Colombiano.

Saldarriaga, A. (2000). Bogotá siglo XX: urbanismo, arquitectura y vida urbana. Bogotá: Departamento Administrativo de Planeación Distrital.

Artículo revista (Fuentes Documentales):

Montaño, A. (2010). Arquitectura para la exhibición de cine en el centro de Bogotá.

Revista de arquitectura/Universidad Católica de Colombia, 12, 81-82.

"Olympia (1915). Bogotá".

"Películas (1916-1919). Bogotá".

Artículo de periódico (Fuentes Documentales):

"El Tiempo, (1914-1927). Bogotá".

Online:

Fundación patrimonio fílmico colombiano (FPFC). (s.f.). Recuperado de http://www. patrimoniofilmico.org.co/index.php?option=com_content\&view=category\&layout=blog \&id $=45 \&$ Itemid $=156$.

«Historia del cine colombiano.» Fundación Patrimonio Fílmico Colombiano (FPFC). (s.f.). Recuperado de <http://www.patrimoniofilmico.org.co/index.php?option=com_conte nt\&view=article\&id=133:historia-del-cine-colombiano\&catid=45:publicaciones\&Item id $=18>$.

«Media publicidad.» Madrid: Centro nacional de Información y Comunicación Educativa (CNICE). (2004). Recuperado de http://recursos.cnice.mec.es/media/publicidad/extras/ docente/PDF/Imprimible01Pub.pdf. 